\title{
Stealth Trading Behaviour in Capital Market: A Literature Review
}

\author{
Ghazali Syamni ${ }^{1}$, Nasir Aziz $^{2}$, Said Musnadi ${ }^{2}$, Faisal ${ }^{2}$ and M. Shabri Abd Madjid ${ }^{2}$ \\ \{syamni_ghazali@yahoo.com,nasirazis@yahoo.com,nadi_alifa@yahoo.com, \\ faisalekam@yunsyiah.ac.id\}
${ }^{1}$ Faculty of Economics and Business, Universitas Malikussaleh, Aceh Utara, Program in Management, Faculty of Economics and Business, Syiah Kuala University, Indonesia \\ ${ }^{2}$ Faculty of Economics and Business, Syiah Kuala University, Indonesia
}

\begin{abstract}
: the behaviour of hiding trade information in the capital market which is called stealth trading currently takes place in various capital markets in the world. This behaviour is performed by investors, in particular informed investors, by not sharing information with other investors during trade transactions. It is aimed to keep others investors from following the informed investors trading transactions in the capital market. Thus, this paper is intended to review and evaluate the existence of stealth trading in various capital markets in the world from an empirical perspective. In general, result of the review finds that, from an empirical perspective, stealth trading behaviour is still inconsistent in various capital markets in the world.
\end{abstract}

Keywords: behaviour, stealth trading, capital, market.

\section{Introduction}

Stealth trading behaviour (ST) is a hypothesis introduced by (Barclay and Warner, 1993) or BW 1993. ST is a behaviour of informed investors who hide information by splitting trading orders in medium sizes. (Barclay and Warner, 1993) explain that the behaviour of information hiding or solving the size of trade into medium size is a reason to keep their ongoing transactions from affecting stock prices changes. There are 2 other reasons according to BW 1993. First, if trading in large numbers at once, the informed investors will regard the information as futile because other investors will follow their actions. Second, small transactions will lead to inefficiency or increased trade cost. Due to ST behaviour, eventually changes in stock prices in the medium size occur in medium stock cumulatively.

Having mentioned the above, the authors conducted several empirical literature studies relating to ST behaviour in capital markets in various countries in the world. So, the purpose of this literature study is to analyse stealth trading behaviour in various capital markets in the world.

\section{Methodology}

The method used in this study is a literature study method about the existence of stealth trading behaviour in various capital markets in the world. Researchers conduct the study by accessing reputable international articles and journals, particularly the Syiah Kuala University library. After getting the articles, the authors then classified them based on developed and developing countries. 


\section{Literature Review}

After BW 1993 introduced the occurrence of ST behaviour in United States's capital market, several studies have also been conducted in various developed countries which mention the ST phenomenon. (Chakravarty, 2001)was the first researcher after BW 1993 who tested and concluded the existence of stealth trading phenomena in individual and institutional investors.

In the past decade research on ST in America and Europe found inconsistent results despite concluding the occurrences of ST behaviour. (Lebedeva, Maug and Schneider, 2009) used equity market transaction data in the USA before and after the implementation of Sarbanes-Oxley act by NASDAQ and NYSE. (Alexander and Peterson, 2007) and (Abad and Pascual, 2011) on the American Stock Exchange concluded that stealth trading occurred in middle-class trading. (Blau, Van Ness and Van Ness, 2009) explained that there was a change in the price of a small trade to a large trade at midday trading. Changes in trading prices are large because at market's opening and closing the informed investor traded high without disclosing information to the market. This result is supported by (Huang, 2011)who explained that ST occurred at the end of the morning session closing or 11:30 am and 14.00 hours. The results of several studies above reveal the existence of stealth trading (ST) behaviour in the market.

Meanwhile, (Blau and Brough, 2012) research using short sale objects concluded that stealth trading behaviour did not occur. Time restraint was one reason that prevented stealth trading behaviour from happening. (Liu and Kaniel, 2004) studied on the NYSE, NASDAQ, French Exchanges, Tokyo and Toronto discovered that informed traders used certain limit orders and were informative. (Menkhoff and Schmeling, 2010b, 2010a) who examined the German's money market and forex market stated that stealth trading practices when a medium order trades. (Verousis and Ap Gwilym, 2013) examined using data on the London Stock Exchange. After controlling the size of the trade it was found that there was a relationship between the size of the trading group and the price which showed the Stealth trading behaviour.

A number of studies in the Chinese region regarding ST behaviour bring various results. (Cai, Cai and Keasey, 2006; Chang, Hsieh and Lai, 2013) mentioned ST the occurrence of ST behaviour in China was characterized by medium and large trade sizes and influence price more with indications during the collection period before the opening of the market. But, research in Taiwan (Blau, Van Ness and Van Ness, 2009; Lin et al., 2014) also found that St Behaviour occurred where the separation of orders was more into the medium. (Hsieh and He, 2014) used Taiwan option data that found this medium order limit as a form of information hiding.

However, (Ligon and Liu, 2013) using data in Taiwan found that stealth trading did not occur. Furthermore, (Kang and Ryu, 2010) stated even though ST occurred but trading occurred in the size of medium prices which failed to provide trade information compared to other trade measures. In addition, (Zhang, Chueh and Hsu, 2015) in Taiwan, revealed that uninformed trading had the highest trading frequency on Monday and Thursday since on those two days more relevant information was conveyed. This finding is different from the others stating stealth trading occurs Monday and Thursday. Research in Japan by (Ascioglu, Comerton-Forde and McInish, 2011) found the existence of stealth trading and how trading groups affected changes in cumulative share prices. Large trade groups obviously have the largest portion in influencing cumulative price changes during high volatility. 
In South Korea, (Webb et al., 2016) using KOSPI 200 market data also mentioned the existence of ST behaviour influenced by small investors but institutional informed investors were more informative and possessed greater influence than individual investors. (Ryu, 2016) using KOSPI 200 data found that stealth trading did not occur. In Australia that stealth trading took place on every trading day caused by medium trading that affected price changes. (Kalev and Pham, 2009) using Australian stock exchange data also found stealth trading on every trading day. In addition, medium investors influenced changes in stock prices, especially on Monday. Large trading sizes trade at opening and closing markets, especially Monday and Friday. (Bjursell et al., 2010) who used data in the futures index, Australia and FTSE UK 100 found the trading frequency of small and large trade categories significantly affecting the volatility of contract futures prices.

In India, (Mishra, McInish and Tripathy, 2015) found ST behaviour but price changes was concentrated more on small trade size while the remaining were influenced by medium trade. Research on the Kuwait Stock Exchange conducted by (Alhashel, 2015) used issue of bull market conditions (good condition) and bear (bad condition). The results of the study found that stealth trading behaviour took place in medium-sized trades when the bull market, while at the time of bear market trading occured when the trading size was small. (Charoenwong and Ding, 2010) in Thailand, discovered ST behaviour. (Aktas and Kryzanowski, 2014) examined BITS 30 in Turkey and came to conclusion that ST was determined by a large trade where price changes occurred at the end of trading. This price change was an intervention of the parties involved in the capital market.

Several studies in Indonesia have not tested stealth trading behaviour deeply. Studies conducted in Indonesia are still on the order of imbalance (Ekaputra, 2014) and price manipulation of (Wibowo, 2009). (Dvořák, 2005; Kholisoh, 2008; Sumiyana, 2008, 2015; Agarwal et al., 2009; Rhee and Wang, 2009; Hanafi and Rhee, 2013; Wang, 2013) all claimed faster and easier disclosure of information would make it easier for investors to conduct larger stock transactions, while (Syamni, 2011; Rokhim and Tanuwijaya, 2015) claimed differences in the current trade with regard to trading day anomalies. This is consistent with (Hanafi and Rhee, 2013) the trade differences caused by match transaction orders.

\section{Conclussion}

This paper is a literature study analysing the existence of stealth trading behaviour (ST) in several capital markets in the world. The results of the literature study show that both developed and country countries are developing stealth trading behaviour inconsistently. Research in America and Europe clearly finds mixed results about stealth trading behaviour. There is an article stating that stealth trading behaviour exists when a price change is indicated by changes in stock prices in the medium size.

In addition, ST requirements occur differently every time and trading day. There are even studies that state that ST behaviour does not occur in short sale trading. Research in China, Japan, Korea and Australia and Asia in general has indicated that stealth behaviour occurred. These results are similar as those done in America and Europe. Even some studies concluded that ST did not take place. Meanwhile, in Indonesia, studies on ST behaviour is not deeply covered and only discusses about the superiority of investor information, order imbalance and price manipulation. 


\section{References}

[1] Abad, D. and Pascual, R. (2011) 'Revisiting the Stealth Trading Hypothesis *', 2011(January). doi: 10.1016/j.jfoodeng.2015.09.009.

[2] Agarwal, S., Faircloth, S., Liu, C. and Ghon Rhee, S. (2009) 'Why do foreign investors underperform domestic investors in trading activities? Evidence from Indonesia', Journal of Financial Markets, 12(1), pp. 32-53. doi: 10.1016/j.finmar.2008.04.001.

[3] Aktas, O. U. and Kryzanowski, L. (2014) 'Market impacts of trades for stocks listed on the Borsa Istanbul', Emerging Markets Review. Elsevier B.V., 20, pp. 152-175. doi: 10.1016/j.ememar.2014.06.002.

[4] Alexander, G. J. and Peterson, M. A. (2007) 'An analysis of trade-size clustering and its relation to stealth trading', Journal of Financial Economics, 84(2), pp. 435-471. doi: 10.1016/j.jfineco.2006.02.005.

[5] Alhashel, B. (2015) 'Does stealth trading coexist with high levels of insider trading? Evidence from Kuwait', Global Finance Journal. Elsevier Inc., 27, pp. 112-118. doi: 10.1016/j.gfj.2015.04.007.

[6] Ascioglu, A., Comerton-Forde, C. and McInish, T. H. (2011) 'Stealth trading: The case of the Tokyo Stock Exchange', Pacific Basin Finance Journal, 19(2), pp. 194-207. doi: 10.1016/j.pacfin.2010.10.001.

[7] Barclay, M. J. and Warner, J. B. (1993) 'Stealth trading and volatility. Which trades move prices?', Journal of Financial Economics, 34(3), pp. 281-305. doi: 10.1016/0304-405X(93)90029-B.

[8] Bjursell, J., Frino, A., Tse, Y. and Wang, G. H. K. (2010) 'Volatility and trading activity following changes in the size of futures contracts', Journal of Empirical Finance. Elsevier B.V., 17(5), pp. 967-980. doi: 10.1016/j.jempfin.2010.08.003.

[9] Blau, B. M. and Brough, T. J. (2012) 'Short sales, stealth trading, and the suspension of the uptick rule', Quarterly Review of Economics and Finance. Board of Trustees of the University of Illinois, 52(1), pp. 38-48. doi: 10.1016/j.qref.2011.12.004.

[10] Blau, B. M., Van Ness, B. F. and Van Ness, R. A. (2009) 'Intraday stealth trading: Which trades move prices during periods of high volume?', Journal of Financial Research, 32(1), pp. 1-21. doi: 10.1111/j.1475-6803.2008.01240.x.

[11] Cai, B. M., Cai, C. X. and Keasey, K. (2006) 'Which trades move prices in emerging markets?: Evidence from China's stock market', Pacific Basin Finance Journal, 14(5), pp. 453-466. doi: 10.1016/j.pacfin.2006.05.001.

[12] Chakravarty, S. (2001) 'Stealth-trading: Which traders' trades move stock prices?', Journal of Financial Economics, 61(2), pp. 289-307. doi: 10.1016/S0304405X(01)00063-0.

[13] Chang, C. C., Hsieh, P. F. and Lai, H. N. (2013) 'The price impact of options and futures volume in after-hours stock market trading', Pacific Basin Finance Journal. Elsevier B.V., 21(1), pp. 984-1007. doi: 10.1016/j.pacfin.2012.07.002.

[14] Charoenwong, C. and Ding, D. (2010) 'Which Trade Sizes Move Stock Prices in a Fully Automated Order-Driven Market? a Case of the Stock Exchange of Thailand', pp. 1-33.

[15] Dvořák, T. (2005) 'Do Domestic Investors Have an Information Advantage ? Evidence from Indonesia', The Journal of Finance, 60(2), pp. 817-839.

[16] Ekaputra, I. A. (2014) 'Impact of foreign and domestic order imbalances on return and volatility-volume relation', Asian Academy of Management Journal of Accounting and Finance, 10(1), pp. 1-19. 
[17] Hanafi, M. and Rhee, S. G. (2013) 'The Wealth Effect of Foreign Investor Presence: Evidence from the Indonesian Market', Management and International Review ..., 2, pp. 157-171. Available at: https://books.google.com/books?hl=en\&lr=\&id=dJaBwAAQBAJ\&oi=fnd\&pg=PA157\&dq=sentiment+source:management+source:science \&ots=U0NPEcMxMt\&sig=mMuP18vrS6Q4XyZunurRgh3P3Ak.

[18] Hsieh, W. liang G. and He, H. R. (2014) 'Informed trading, trading strategies and the information content of trading volume: Evidence from the Taiwan index options market', Journal of International Financial Markets, Institutions and Money. Elsevier B.V., 31(1), pp. 187-215. doi: 10.1016/j.intfin.2014.03.012.

[19] Huang, H. C. (2011) 'An analysis of intraday return - Order imbalance relation to stealth trading', Investment Management and Financial Innovations, 8(1), pp. 234-242.

[20] Kalev, P. S. and Pham, L. T. (2009) 'Intraweek and intraday trade patterns and dynamics', Pacific Basin Finance Journal. Elsevier B.V., 17(5), pp. 547-564. doi: 10.1016/j.pacfin.2009.05.002.

[21] Kang, J. and Ryu, D. (2010) 'Which Trades Move Asset Prices? An Analysis of Futures Trading Data', Emerging Markets Finance and Trade, 46(0), pp. 7-22. doi: 10.2753/REE1540-496X4603S101.

[22] Kholisoh, L. (2008) 'Perilaku Aktivitas Perdagangan Intrahari', 13(1), pp. 16-26.

[23] Lebedeva, O., Maug, E. G. and Schneider, C. (2009) Stealth Trading by Corporate Insiders, Ssrn. doi: 10.2139/ssrn.1509607.

[24] Ligon, J. A. and Liu, H. C. (2013) 'The relation of trade size and price contribution in a traditional foreign exchange brokered market', Pacific Basin Finance Journal. Elsevier B.V., 21(1), pp. 1024-1045. doi: 10.1016/j.pacfin.2012.08.002.

[25] Lin, C. T., Chou, L. Der, Chen, Y. M. and Tseng, L. M. (2014) 'A hybrid economic indices based short-term load forecasting system', International Journal of Electrical Power and Energy Systems. Elsevier Ltd, 54, pp. 293-305. doi: 10.1016/j.ijepes.2013.07.017.

[26] Liu, H. and Kaniel, R. (2004) So What Orders Do Informed Traders Use?, Ssrn. G10;G14;G29. doi: 10.2139/ssrn.602581.

[27] Menkhoff, L. and Schmeling, M. (2010a) 'Trader see, trader do: How do (small) FX traders react to large counterparties' trades?', Journal of International Money and Finance. Elsevier Ltd, 29(7), pp. 1283-1302. doi: 10.1016/j.jimonfin.2010.04.001.

[28] Menkhoff, L. and Schmeling, M. (2010b) 'Whose trades convey information? Evidence from a cross-section of traders', Journal of Financial Markets, 13(1), pp. 101-128. doi: 10.1016/j.finmar.2009.08.001.

[29] Mishra, A. K., McInish, T. H. and Tripathy, T. (2015) 'Price movement and trade size on the National Stock Exchange of India', Applied Economics, 47(45), pp. 4847-4854. doi: 10.1080/00036846.2015.1037436.

[30] Rhee, S. G. and Wang, J. (2009) 'Foreign institutional ownership and stock market liquidity: Evidence from Indonesia', Journal of Banking and Finance. Elsevier B.V., 33(7), pp. 1312-1324. doi: 10.1016/j.jbankfin.2009.01.008.

[31] Rokhim, R. and Tanuwijaya, H. (2015) 'Market Anomalies and Intraday Return Indonesia Stock Exchange', International Journal of Economics \& Management Sciences, 2015(5). doi: 10.4172/21626359.1000253.

[32] Ryu, D. (2016) 'Considering all microstructure effects: The extension of a trade indicator model', Economics Letters. Elsevier B.V., 146, pp. 107-110. doi: 10.1016/j.econlet.2016.07.025.

[33] Sumiyana (2008) 'Day of the Week dan Monday Effect : Fenomena Yang Terbuktikan 
Tidak Konsisten Di Pasar Modal Indonesia', Jurnal Manajemen Teori dan Terapan, 1(1), pp. 1-30.

[34] Sumiyana, S. (2015) 'Noise atau kedatangan informasi: sebuah fenomena spesifik perilaku harga saham di pasar modal Indonesia studi empiris berbasis data intraday, Bursa Efek Jakartata 1999-2006', Journal of Indonesian Economy and Business, 22(3), pp. 192-218.

[35] Syamni, G. (2011) 'Peran order investor dalam menjelaskan terbentuknya pola volume perdagangan di Bursa Efek Indonesia', Jurnal Akuntansi dan Keuangan Indonesia, 8(1), pp. 94-106.

[36] Verousis, T. and Ap Gwilym, O. (2013) 'Trade size clustering and the cost of trading at the London Stock Exchange', International Review of Financial Analysis. Elsevier Inc., 27, pp. 91-102. doi: 10.1016/j.irfa.2012.08.007.

[37] Wang, J. (2013) 'The impact of foreign ownership on stock volatility in Indonesia', Asia-Pacific Journal of Financial Studies, 42(3), pp. 493-509. doi: 10.1111/ajfs.12022.

[38] Webb, R. I., Ryu, D., Ryu, D. and Han, J. (2016) 'The price impact of futures trades and their intraday seasonality', Emerging Markets Review. Elsevier B.V., 26, pp. 8098. doi: 10.1016/j.ememar.2016.01.002.

[39] Wibowo, B. (2009) 'Price manipulation in indonesian capital market: empirical analysis on stockbroker's behavior and interaction pattern between domestic investors and foreign investors', Indonesian Capital Market Review, II, pp. 63-71.

[40] Zhang, T. W., Chueh, H. and Hsu, Y. H. (2015) 'Day-of-the-week trading patterns of informed and uninformed traders in Taiwan's foreign exchange market', Economic Modelling. Elsevier B.V., 47, pp. 271-279. doi: 10.1016/j.econmod.2015.03.004. 